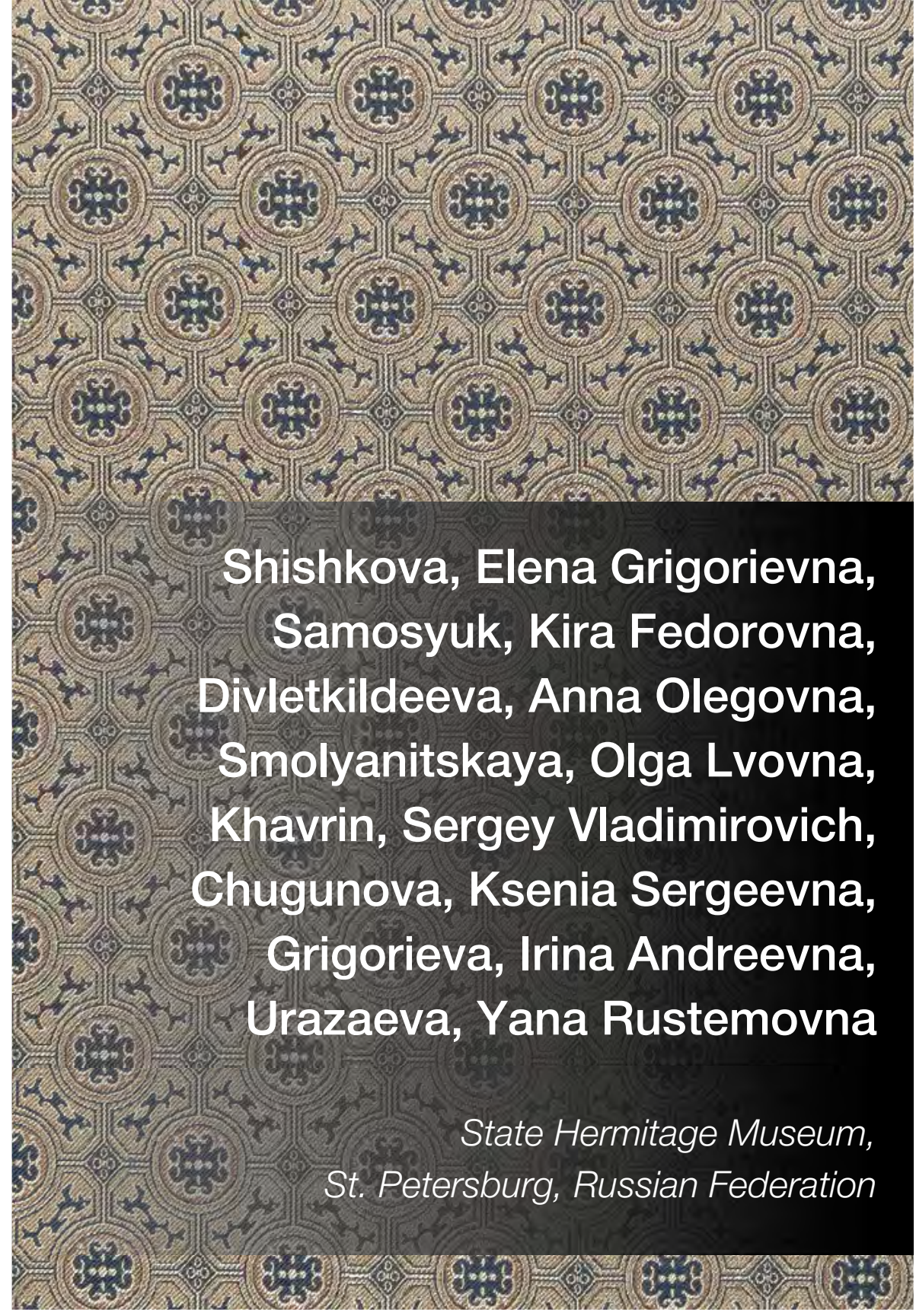

Шишкова Елена Григорьевна, Самосюк Кира Федоровна, Дивлеткильдеева Анна Олеговна, Смоляницкая Ольга Львовна, Хаврин Сергей Владимирович, Чугунова Ксения Сергеевна, Григорьева Ирина Андреевна, Уразаева Яна Рустэмовна

Государственный Эрмитаж,

г. Санкт-Петербург, Российская Федерация

\title{
РЕСТАВРАЦИЯ КИТАЙСКОГО
}

\section{АЛЬБОМА XVIII ВЕКА}

RESTORATION OF 18TH CENTURY

CHINESE ALBUM 


\section{БЛАГОДАРНОСТИ}

Авторы благодарят за содействие в проведении реставрационных работ фонд «The Coca-Cola Foundation», Благотворительный фонд В. Потанина, переводчицу текста на английский язык Кристину Барнард, а также сотрудников лаборатории научной реставрации восточной живописи, принимавших участие в реставрации альбома: А.О. Андрееву, Е.А. Маслову, В.А. Румянцеву, К.В. Ягину и фотографра редакционно-издательского отдела К.В. Синявского.

\section{ACKNOWLEDGMENTS}

The authors thank the Coca-Cola Foundation, the V. Potanin Charitable Foundation, Christine Barnard (MA, MITI, translator), as well as the staff of the Scientific Restoration of Oriental Painting of the State Hermitage Museum who took part in the restoration of the album: A.O. Andreeva, E.A. Maslova, V.A. Rumyantseva, K.V. Yagina and the photographer of the Editorial and Publishing Department K.V. Sinyavsky.

\section{АННОТАЦИЯ}

Цель данного исследования - познакомить специалистов, занимающихся изучением и реставрацией произведений китайской живописи, с опытом, полученным в Государственном Эрмитаже. В процессе изучения текстов «Альбома рисунков. Путешествие императора Цяньлуна на юг Китая» хранителем К.Ф. Самосюк была установлена дата его создания - 1751-1758 годы. Альбом с китайской живописью был исследован всесторонне: проведены физико-химические и биологические исследования, которые позволили определить методику его реставрации. В России мало информации о реставрации альбомов такого рода. Исследование и реставрация китайской живописи осложняется хрупкостью материалов - бумаги и шелка, а также утонченностью техники живописи, поэтому были выбраны неразрушающие методы исследования без взятия проб. Рассматривались также этические проблемы. Были применены физический, химический и биологический анализы для определения подходящего метода реставрации. Биологические исследования подтвердили необходимость замены старых, обветшавших страниц альбома новыми. Для реставрации и сохранения альбома были использованы традиционные китайские методы реставрации и собственный опыт. Об исследовании и реставрации китайской живописи и каллиграфии, помещенных в альбомы, не так много информации. Наряду с другими источниками впервые в отечественной практике было использовано «Иллюстрированное руководство по монтированию китайской каллиграфии и живописи» Янь Гуйжуна, 2013. В статье также рассматривается проблема адаптации альбомов с живописью и каллиграфией к новым требованиям хранения и экспонирования графики. Изменение исторической формы монтирования листов с изображениями было вызвано сильным разрушением конструкции альбома. Новая форма хранения позволила выставлять альбом отдельными листами на различных тематических выставках с возможностью их ротации на экспозиции. В данной статье показан логический ход выбора методики реставрации, основанный на результатах исследований памятника и сочетании традиционных и современных методов реставрации.

КЛЮЧЕВЫЕ СЛОВА: КИтайская Живопись, каллиграфия, альбом, китайская бумага, китайский шелк, консервация, реставрация, физикохимические исследования, биологические исследования, экспонирование, восточная живопись, Государственный Эрмитаж.

\section{ABSTRACT}

The aim of the article is to share our experience of restoring the Album of Drawings. The Emperor Qian Long's Tour of Inspection to Southern China. Curator K.F. Samosyuk has dated the album to 17511758.

There is little information in Russia on restoring albums of this kind. Restoration of painting on paper and silk is complicated by the fragility of the support material and painting technique; we therefore chose non - destructive research methods without taking samples. Ethical problems were also considered.

For the first time we used physical, chemical and biological analysis to determine the appropriate restoration method. Biological research led us to replace old, faded album pages with new ones. We then used traditional Chinese restoration methods and our own experience to restore and preserve the album.

Along with other sources, for the first time in Russia, Yan Guirong's Illustrated Instructions for the Mounting of Chinese Calligraphy and Painting, 2013 was used. The key factor, though, was the experience we gained during research secondments at Shanghai Museum.

We also examine the problem of adapting painting and calligraphy albums to new requirements for the preservation and exhibiting of graphic art. Historically, album pages with illustrations were mounted in pairs and glued together. Because of the album's severe state of deterioration we decided to mount the pages on separate sheets. This new form of preservation has enabled separate pages from the album to be shown at differently - themed exhibitions and for rotation to take place.

The article shows the logical process involved in choice of restoration method based on our research findings and a combination of traditional and modern restoration methods.

KEYWORDS: Chinese painting, calligraphy, album, Chinese paper, Chinese silk, conservation, restoration, physical and chemical research, biological research, exhibiting, oriental painting, State Hermitage Museum. 


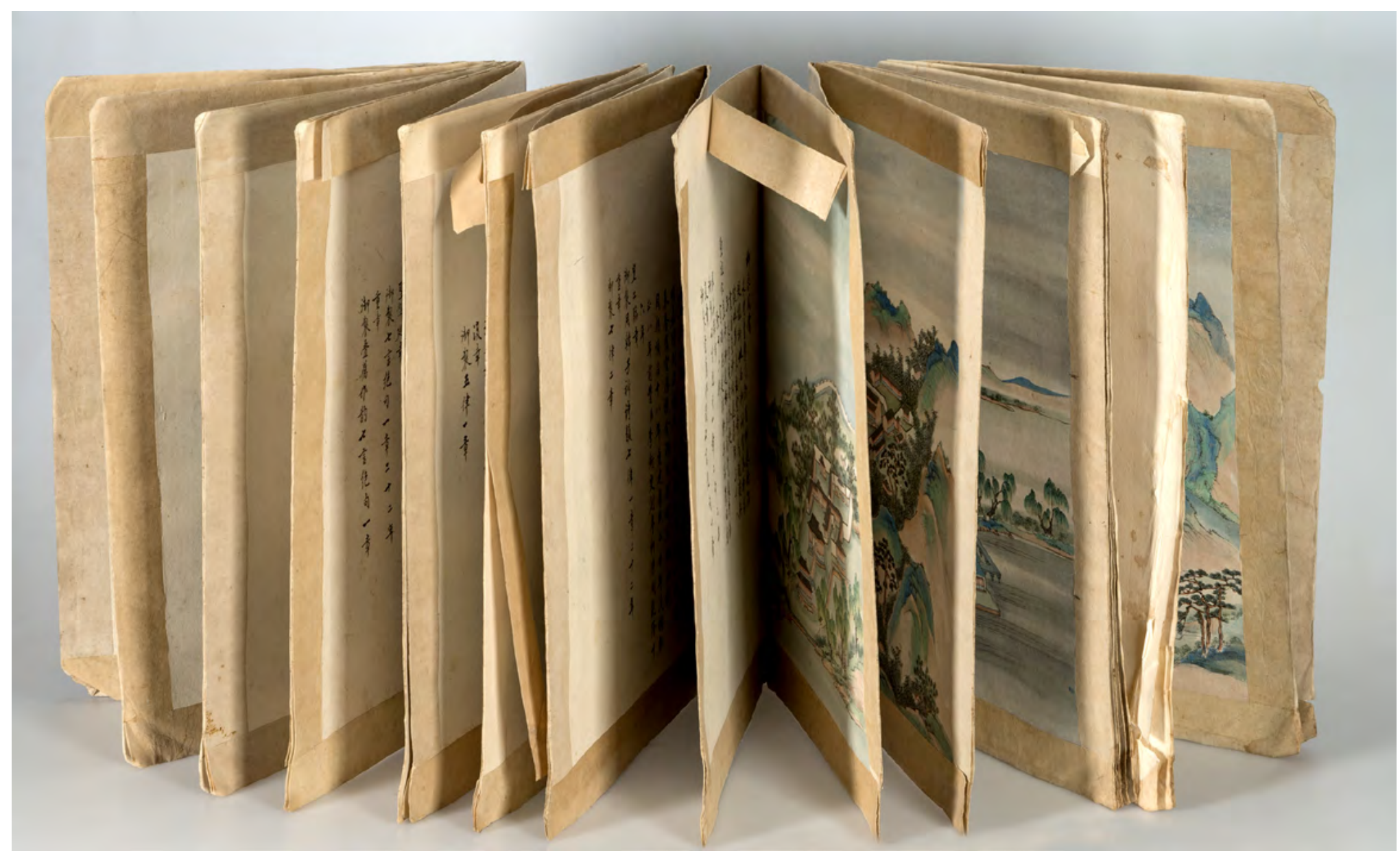

1. «Альбом рисунков.

Путешествие

императора

Цяньлуна на юг Китая».

Китай,

династия Цин,

1751, 1758 гг.

Государственный

Эрмитаж.

Фотография альбома

до реставрации.

Автор фотографии:

К.В. Синявский

\section{Введение}

В 2017 году в лабораторию научной реставрации восточной живописи поступил на реставрацию «Альбом рисунков. Путешествие императора Цяньлуна на юг Китая». Альбом находился в плачевном состоянии: пыльный, в пятнах, с растрепанным блоком без крышек и расслоившимися листами. Но, как выяснила хранитель К.Ф. Самосюк при изучении текстов, которые сопровождали пейзажные картины, этот альбом является редким памятником китайского искусства. Он нуждался в серьезной реставрации (рис. 1).

Данный альбом с живописью и каллиграфией посвящен одной из инспекционных поездок императора Цяньлуна (даты жизни 25 сентября 1711 г.— 7 февраля 1799 г.) на юг в 1751 и 1758 годах (рис. 2). Альбом брошюрован в форме «бабочки» - распашной тип альбома, в котором страницы переворачиваются слева направо, парные листы склеены с соседними по краям [3, с. 178].

В развернутом виде все правые листы альбома представляют собой архитектурные пейзажи. На левых листах полускорописью написан текст. Живописные изображения выполнены в технике клеевой живописи, тексты написаны черной тушью.

Первая строка текста является названием места. Далее следует описание архитектурного пейзажа и географические названия изображенной местности. Заключительные строки содержат дату посещения императором Цяньлуном данного конкретного места и ссылку на то, что в память об этом событии император сочинил стихи. Сами стихи не приводятся. Известно, что Цяньлун написал 43 тысячи различных стихов, большей частью о тех местах, которые он посетил, и событиях, связанных с ними.

Имени художника, его печати или же печати самого Цяньлуна на листах нет, так же как нет никаких пометок на обложке. Точных аналогий, которые бы повторяли композиции и детали пейзажа, не найдено. Сюжет инспекционной поездки Цяньлуна и его деда императора Канси был необычайно популярен и имел государственное значение, свита состояла из двух тысяч человек. Целая группа художников сопровождала императора - они увековечивали каждый его визит — и состояла из главного мастера Сюй Яна и его помощников, каждый из которых отличался умением писать определенные сюжеты пейзажи, архитектуру, людей и т.д. Главным итогом работы стало 12 свитков.

Известно, что подготовительная работа заняла три года и была окончена не раньше 1770 года, хотя точных сведений у нас нет. Шестой свиток работы Сюй Яна хранится в музее Метрополитен.

Наряду со свитками было написано и несколько альбомов. Один хранится в музее Гугун 


\section{2. Портрет императора}

Цяньлуна в парадном

одеянии.

Вертикальный свиток.

Шелк, водяные краски.

Фото: wikimedia.org

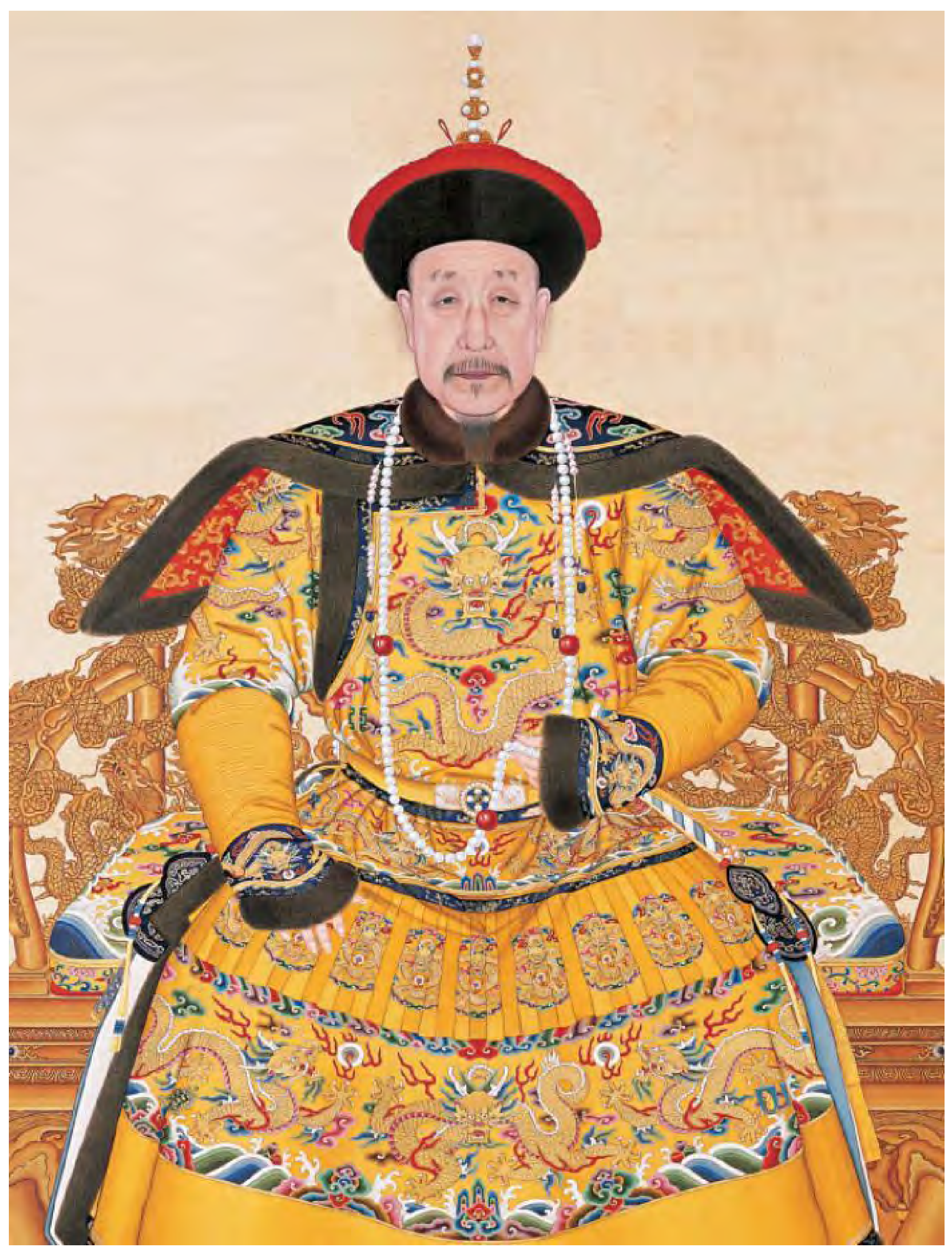


в Пекине и написан другим мастером, не автором эрмитажного альбома. Второй альбом хранится в Британской библиотеке. Эрмитажный альбом отличается стилистически и художественно от двух других, очевидно, что они были написаны разными художниками [6, с. 74, 79].

\section{Этические проблемы реставрации живописи в альбоме}

Проблема реставрации живописи и графики, помещенных в альбомы, актуальна для многих музеев и затрагивает этические вопросы [5, с. 35-54].

Это связано с тем, что в современных условиях интенсивного потока информации увеличился обмен выставками произведений искусства, и нередко листы с живописью и рисунками изымаются из альбомов. Альбомы, которые создавались как своего рода маленькие коллекции рисунков или гравюр, повествующих о каких-либо событиях или памятниках, были также для них формой хранения, защищающей от воздействия внешней среды.

Этические проблемы выступают на первый план при использовании альбомов с произведениями графики для выставок. Альбом в целом является единым памятником, то есть ОН состоит не только из рисунков или гравюр, но также из переплета и декоративных элементов, относящихся, как правило, к одному времени. Как только произведения графики вынимаются из альбома, они становятся разрозненными памятниками. Кроме того, со временем переплеты, папки или футляры безвозвратно теряют своего «хозяина» - коллекцию графики.

Альбом с китайской живописью и каллиграфией «Путешествие императора Цяньлуна» относится к XVIII веку - периоду расцвета китайской живописи. Мы можем только предположить, что первоначально листы с живописью и каллиграфией были дублированы на хорошую бумагу и помещены в традиционный китайский переплет, украшенный шелком, парчой или лаковыми панелями [3, с. 178-179].

Эрмитажный альбом имел скромное обрамление из подкрашенной в охристый цвет бумаги. Местами оно было приклеено небрежно и не закрывало края живописи и каллиграфии. Оригинальные крышки не сохранились, листы большей частью были утрачены, о чем свидетельствуют китайские иероглисы с нумерацией, перенесенные с прежнего бумажного обрамления,- - указаны с 27-го по 40-й листы (рис. 3). Можно предположить, что первоначально листов было 40, а сохранилось только 14.

В процессе обследования альбома и живописных изображений стало очевидным, что листы ранее были «реставрированы» и, возможно, не раз: сохранились не только подклейки разрывов, восполнения утрат, но и старые тонировки и поновления красочного слоя.

Сами изображения и тексты сохранились достаточно хорошо, за исключением небольших участков осыпей зеленой и голубой красок, а также потертостей и царапин. Более всего пострадал 14-й лист: его половина с текстом была утрачена, как и крышки альбома, и он оказался не защищенным от воздействия внешней среды.

О высоком качестве рисунков говорит не только изысканная манера письма и каллиграфии, но и то, что краски были тонко перетерты, что позволило им хорошо сохраниться благодаря сильному сцеплению с бумагой.

\section{Обзор научных источников}

В процессе работы над альбомом были изучены различные литературные источники. Следует выделить статью Клаудии Браун (Claudia Brown) [7], где содержится информация об аналогичных альбомах «путешествий императора» в других музеях мира, что помогло хранителю атрибутировать альбом [7, p. 74, fig, 3,8; p. 79, fig. 3.10; p. 132-133, fig 7.14]. Что касается техники монтирования китайской живописи, то исследование В.Г. Белозёровой [1] является наиболее полным и содержит перевод книги известного мастера конца XX века Фэн Пэншэна. Из последних работ, посвященных практике реставрации китайской живописи, интересен учебник шанхайского мастера Янь Гуйжун «Иллюстрированное руководство по монтированию китайской каллиграфии и живописи» [13]. Также следует отметить статью П.С. Одиноковой [4], непосредственно связанную с темой исследования. Для технологических исследований были привлечены различные статьи и монографии, в которых содержатся указания на использованные методы исследования. Среди них основными являются диссертация О.Л. Смоляницкой [5] и монография А.И. Косолапова [2]. Для сравнительного анализа инфракрасного спектра (ИК-спектра) клея были использованы данные из статьи Бенедикто де Кампос Видаля и Марии Луизы Мелло (Benedicto de Campos Vidal, Maria Luiza Silveira Mello) [8]. Также полезна статья Е.Г. Шишковой [6], где рассматриваются этические проблемы реставрации произведений живописи и графики, хранящихся в альбомах.

\section{Методы исследования}

В случае, когда памятник требует нестандартного подхода, необходимо провести детальное исследование с применением современных аналитических методов, которые могут помочь определить программу реставрации и выбрать наиболее безопасные и эффективные реставрационные методики. 


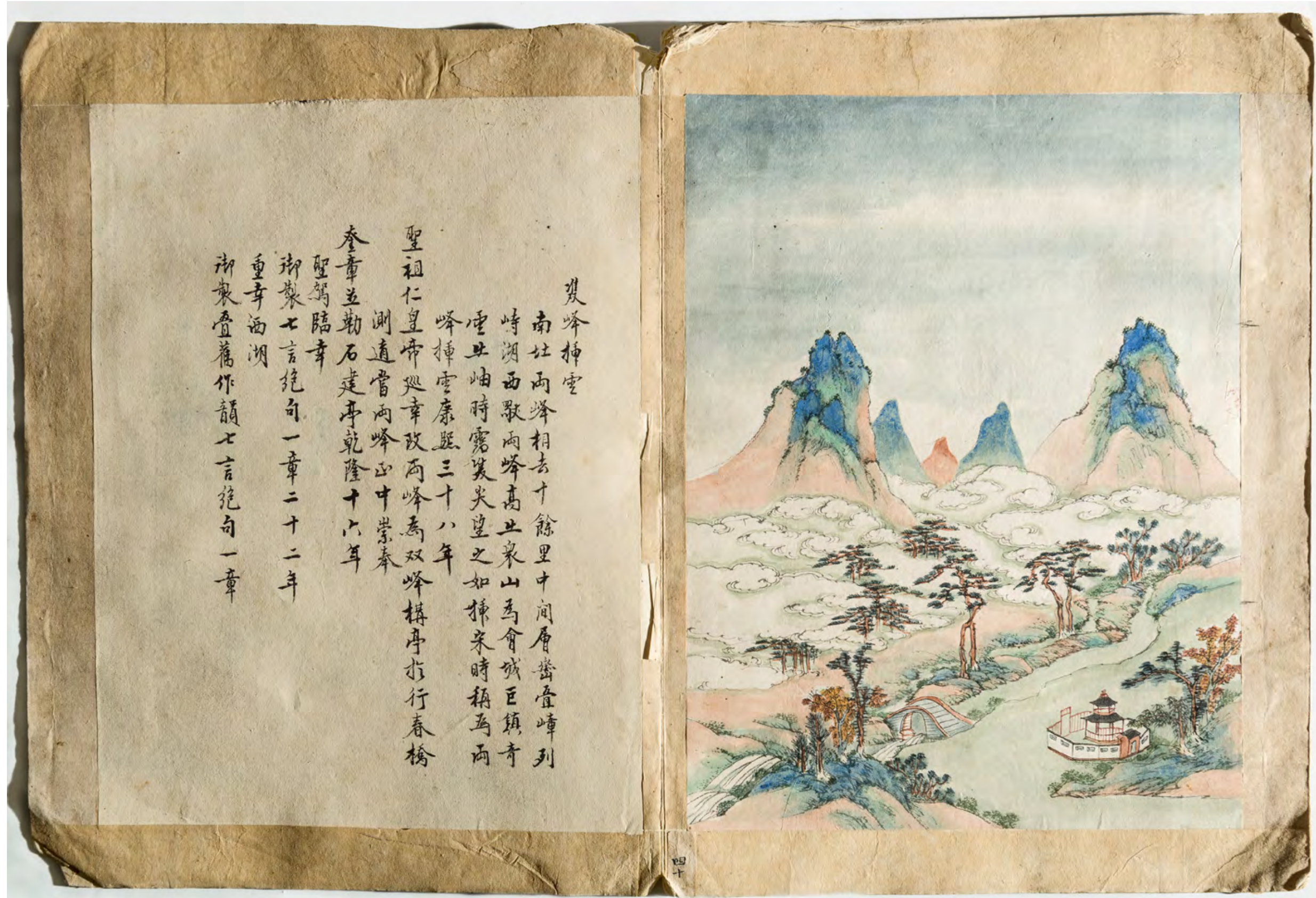

\section{3. Лист № 18}

с пагинацией,

\section{перенесенной}

со старых листов,

\section{до реставрации.}

«Альбом рисунков.

Путешествие императора

Цяньлуна на юг Китая».

Китай,

династия Цин,

1751, 1758 гг.,

Государственный

Эрмитаж.

Автор фотографии:

К.В. Синявский
Для уточнения техники живописи пейзажей и времени их создания было использовано различное оборудование. Исследование пигментов одного из рисунков (лист № 14) альбома «Путешествие императора Цяньлуна на юг Китая» проводилось в отделе научно-технологической экспертизы Государственного Эрмитажа.

В процессе исследования рисунка были использованы следующие инструментальные методы: оптическая микроскопия («Leika M60»; «Zeiss, Stemi 508»), рентгенофлуоресцентный анализ (РФА, XRF-спектрометр «ArtTAX» (RÖNTEC, Bruker)), инфракрасная Фурье-микроспектроскопия (ИК-Фурье спектрометр «Tensor 37» с микроскопом «Hyperion 1000»), рентгенофазовый анализ ${ }^{3}$ (XRD, микродифрактометр «Дифрей-401», АО «Научные приборы»).

При работе с музейными коллекциями предпочтение отдается комплексному подходу [2; 10] и неразрушающим методам исследования [11], не требующим отбора проб, таким как оптическая микроскопия и рентгенофлуоресцентный анализ [9] (рис. 4). Оптическая микроскопия позволяет получить детальную информацию о морфологических особенностях изучаемых предметов (рис. 5).

Для уточнения молекулярного и фазового состава синих и зеленых пигментов применялись инфракрасная Фурье-микроспектроскопия и рентгенофазовый анализ. По результатам всех проведенных исследований на рисунке были определены следующие минеральные пигменты: свинцовые белила, киноварь (рис. 6), азурит, малахит (рис. 7), охры [12].

Бумага самих рисунков и текстов была высокого качества: она практически не изменилась в цвете, оставаясь такой же белой и эластичной. Даже пожелтевший окислившийся со временем 

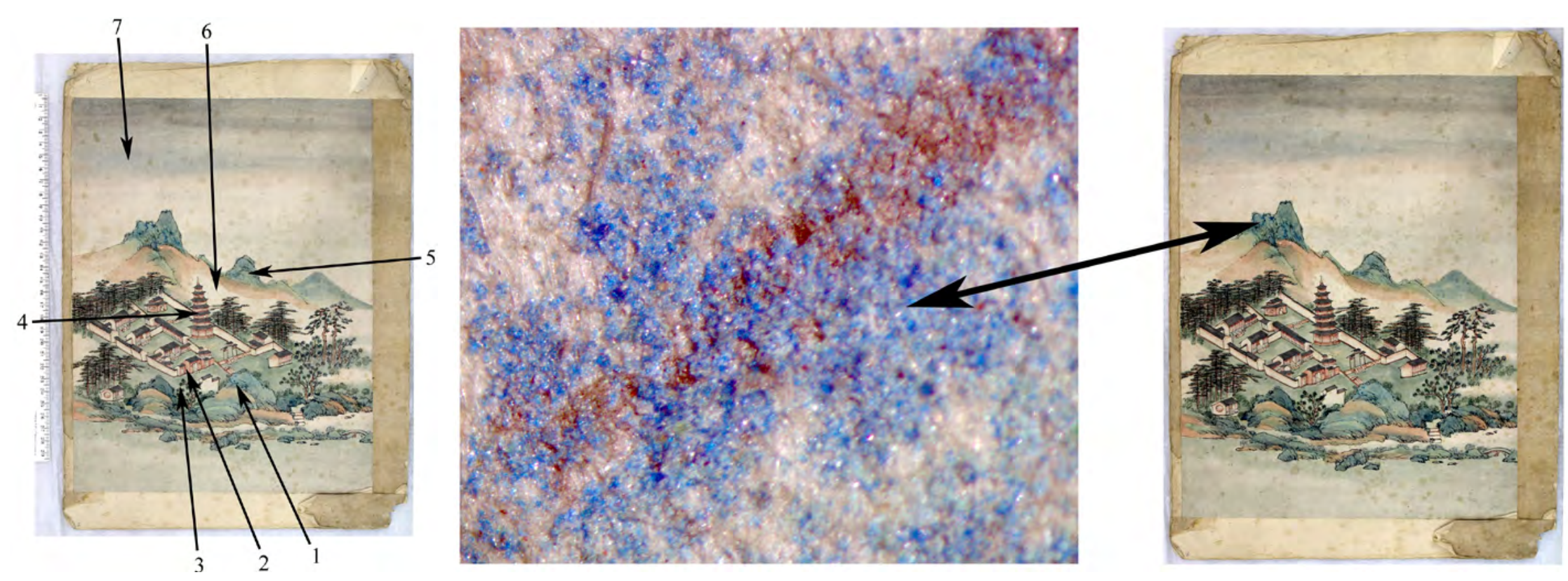

клей, использованный при дублировании, не смог сильно повредить ей, тогда как на бумаге обрамлений альбомных листов сохранились бурые пятна клея.

Чтобы дополнить картину причин повреждения альбомных листов, были взяты пробы клея с обрамления, там, где он лежал пастозно (рис. 8).

Исследование клея проводились в лаборатории научной реставрации драгоценных и археологических металлов Государственного Эрмитажа.

Небольшой образец клея исследовали с помощью ИК-микроскопа Thermo Scienific Nikolet iN10 в режиме нарушенного полного внутреннего отражения (НПВО). Измерения делались при комнатной температуре в спектральном диапазоне 4000-600 см-1, с разрешением 8 см-1, спектры регистрировались по 256 сканам.

Для интерпретации спектров использовалась программа OMNIC, укомплектованная библиотекой спектров широкого класса веществ, что позволяет достаточно точно идентисицировать исследуемый образец. Спектры снимались непосредственно с пробы без дополнительной подготовки. В результате был получен высокоинформативный спектр с характерными областями поглощения. В дальнейшем спектры сравнивались с используемой в лаборатории базой данных ИК-спектров образцов. Автоматический поиск показал сходство спектра со спектром коллагена (рис. 9). Полученный ИК-спектр с полосами поглощения, характерными для белковых соединений, также сравнивали с данными научной литературы [8, с. 287].

Многослойная основа альбомных листов, на которую были дублированы живописные изображения и каллиграфия, состояла из шести склеенных между собою листов китайской бумаги среднего качества, судя по интенсивному пожелтению. Процессы разрушения были ускорены тем, что альбом находился во влажной среде: края листов размокли и расслоились, от этого образовались затёки, а также пятна плесени и фоксингов.

Биологические исследования - важная часть реставрационного процесса. Основными вредителями экспонатов на бумажной основе считаются микроскопические, или плесневые, грибы (микромицеты). Бумага является легкодоступным питательным субстратом для микроскопических грибов; наличие клея и связующих красочного слоя способствует развитию микроорганизмов. Споры микроскопических грибов постоянно присутствуют в окружающей среде, однако их рост начинается только при повышении влажности. Развиваясь на бумаге, плесневые грибы вызывают деструкцию бумаги вплоть до ее полного разрушения.

Основными методами микологических исследований являются анализы при помощи микроскопов и посевы на питательные среды. В связи с тем, что на листах альбома были обнаружены фоксинги, а также пятна и налёты, внешне схожие с колониями микромицетов, было проведено микологическое исследование мест повреждений.

Пробы с поверхности пятен и налетов были отобраны при помощи стерильных зондовпробоотборников. Для микроскопических анализов использовали биологический микроскоп «МБИ-15» и стереомикроскоп «Lеica MZ-16». Образцы исследовали в проходящем и отраженном свете при увеличениях 160x-700х. Для выявления жизнеспособных спор плесневых грибов применяли посевы на питательную среду
4. Места проведения рентгенофлуоресцентного анализа для участков рисунка № 14 следующих цветов: 1 - синий, 2 - розовый, 3 - зеленый, 4 - серый,

5 - голубой, 6 - фон бумаги, 7 - серо-голубой.

Лист № 14

до реставрации.

Государственный

Эрмитаж.

Автор фотографии: К.С. Чугунова

5. Фрагмент рисунка с изображения горы (синий пигмент азурит).

Лист № 14

до реставрации. Государственный Эрмитаж.

Автор фотографии: К.С. Чугунова 


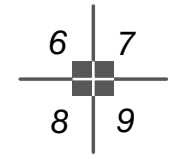

6. Пример РФА-спектра. Спектр точки 2 с рис. 4 (киноварь, охра, свинцовые белила в следах).

Лист № 14 до реставрации. Государственный Эрмитаж.

Автор фотографии: К.С. Чугунова

\section{7. ИК-спектры:} зеленого пигмента с рисунка и малахита (RRUFF Database, R050508).

Лист № 14 до реставрации. Государственный Эрмитаж. Автор фотограсии: И.А. Григорьева

\section{8. Образец клея} с альбомного листа № 18.

Государственный Эрмитаж. Автор фотограсии: Я.Р. Уразаева

\section{9. Лист № 18.}

\section{ИК-спектр клея;}

ИК-спектр коллагена.

Государственный

Эрмитаж.

Автор фотографии: Я.Р. Уразаева
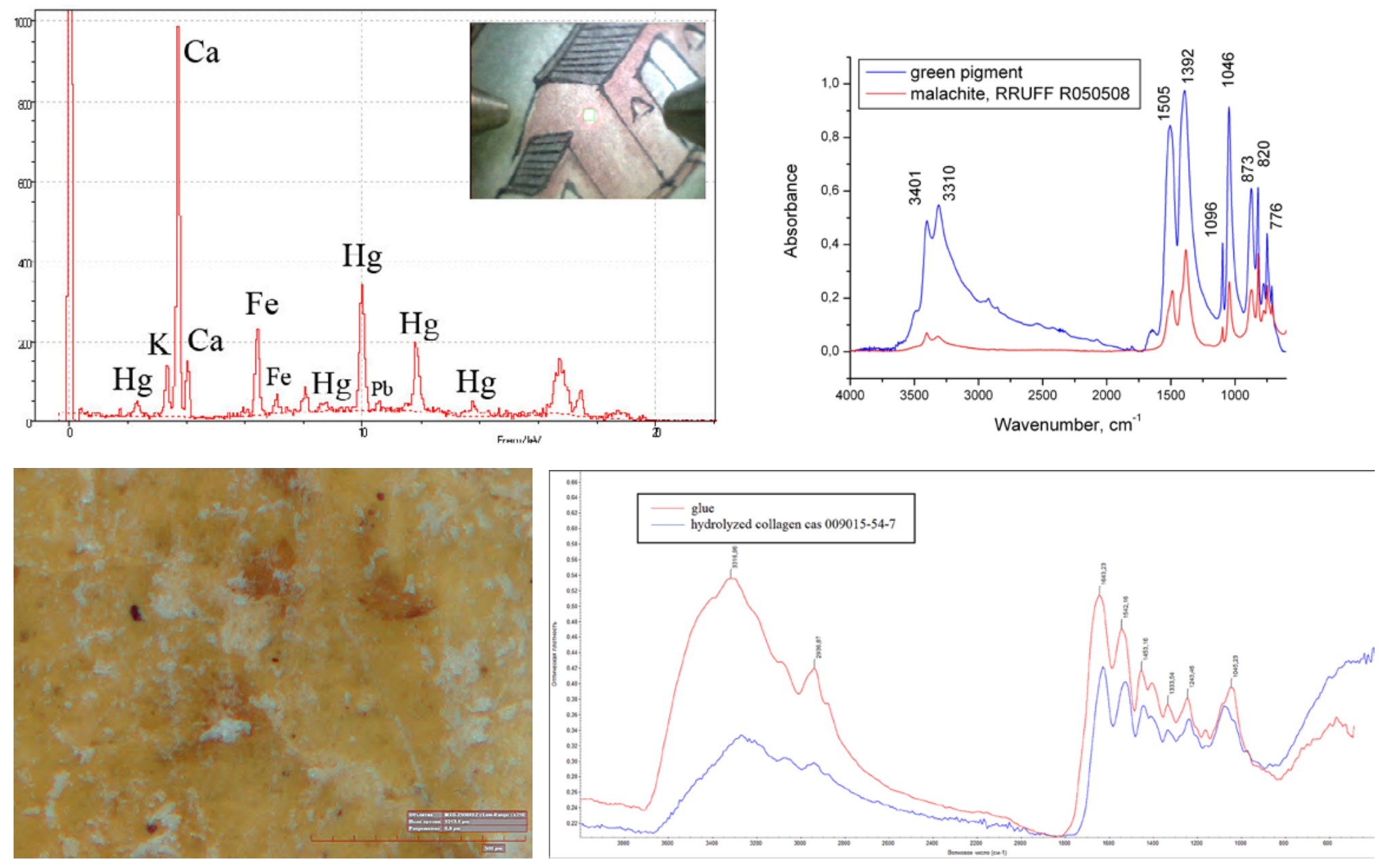

(агар Чапека) в чашки Петри, а затем пробы культивировали при 26о С в течение 28 суток [5, c. 55-57].

Микроскопический анализ проб, взятых из мест образования пятен, обнаружил старые десормированные споры микроскопических грибов. При посевах на питательные среды рост микроорганизмов отсутствовал. Присутствие нежизнеспособных спор грибов в составе давних повреждений в настоящий момент не представляет опасности для материалов, поэтому для их удаления была рекомендована обычная механическая очистка.

По результатам проведенного комплекса аналитических исследований были сделаны следующие выводы:

- состав пигментов не противоречит атрибуции пейзажной живописи XVIII века;

- исследованный клей, жесткий бурого цвета, с большой степенью вероятности можно отнести к группе животных клеёв;

- последствия жизнедеятельности микроорганизмов, ослабивших клей между дублированными листами бумаги, были так велики, что утвердили в решении заменить старые, поврежденные листы-основы в целях сохранения живописи.

\section{Реставрационные операции}

Перед хранителем и реставраторами встала непростая задача в выборе подхода к реставрации данного памятника. Первоначально было отдано предпочтение методам консервации: сохранению альбома в том виде, в каком он дошел до нас, ограничиваясь консервационными мерами дезинфекцией, очисткой листов от пыли и загрязнений, подклейкой разрывов, расслоившихся альбомных листов и восполнением утрат основы.

Однако при ближайшем рассмотрении стало очевидно, что листы с живописью и каллиграфией - «средники» - из-за деструкции клея местами отслоились от альбомных листов «Колодок» [1, с. 204]. Отслоение листов было вызвано тем, что микроорганизмы «съели» пшеничный клей, на который были дублированы листы с изображениями, тем самым нарушив связь оригиналов с альбомными листами (рис. 10).

Эстетическое восприятие памятника также было искажено влиянием временных наслоений следами бытования. В том виде, в котором альбом дошел до нас, с трудом угадывалась его «императорская принадлежность».

Решение о реставрации приходило постепенно, можно сказать, «шаг за шагом». После каждой операции начиналось обсуждение состояния 


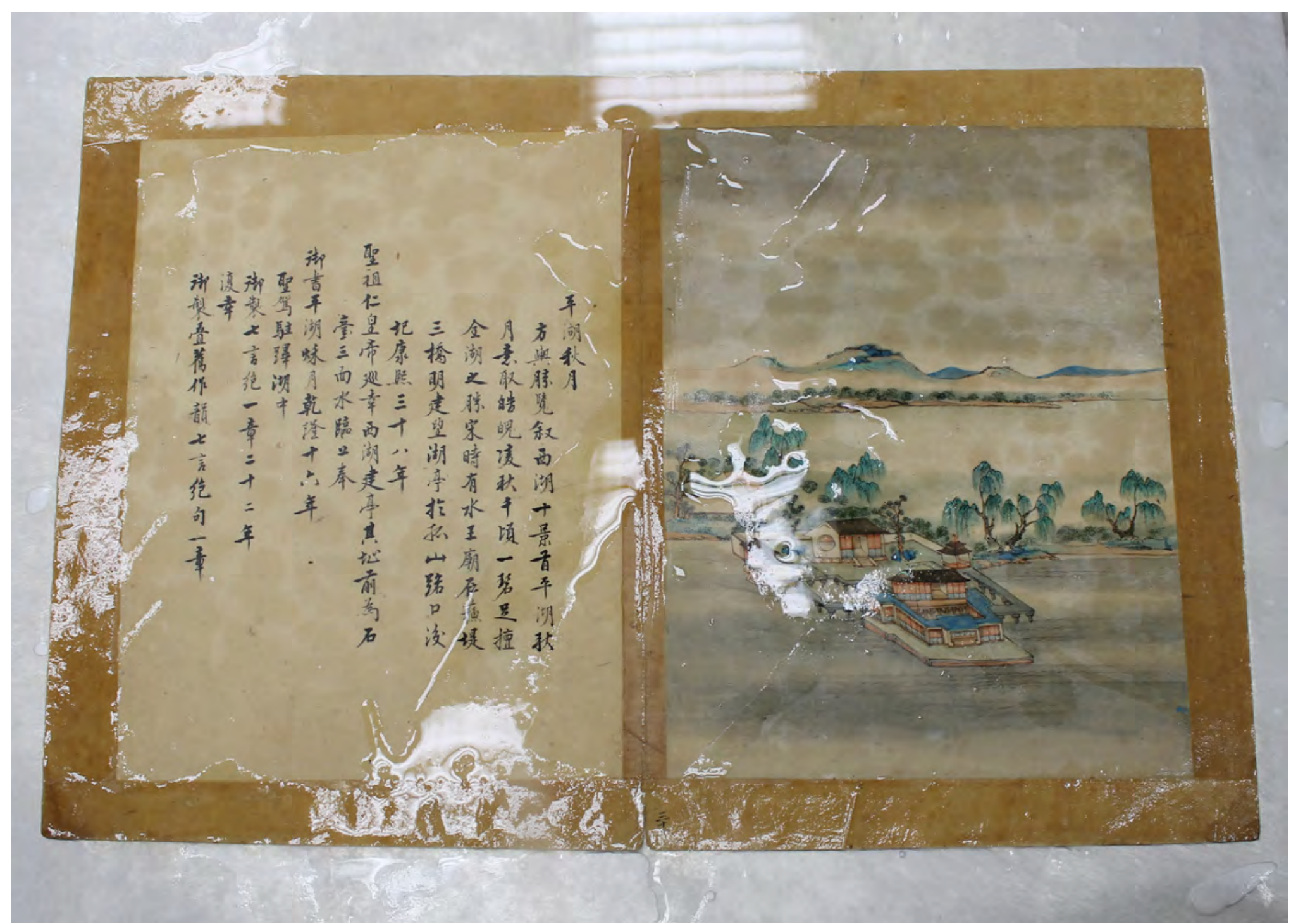

альбома и принималось решение о последующих мероприятиях. Так, после дезинфекции и очистки от загрязнений стало видно, что бумага посвежела, но по-прежнему выглядела неопрятно. На принятие решения о замене старых альбомных листов на новые в большой степени повлияли результаты биологических исследований и физическое состояние многослойной основы листов.

После обобщения мнения специалистов - миколога, химиков, физиков, реставраторов и хранителя - было принято решение о консервации старых альбомных листов и замене их на новые, как основы для редкого памятника живописи и каллиграфии.

Таким образом, была определена программа реставрации альбома. Первым этапом реставрации явилась очистка листов от загрязнений — это обязательная операция перед водной обработкой бумаги. Очистка проводилась двумя способами: мягкой беличьей кистью и латексным спонжем только на участках, свободных от изображения, и альбомных листах с обрамлениями.

Поскольку демонтаж листов с изображениями и текстами предполагалось провести методом полного увлажнения в теплой воде, то предварительно красочный слой был закреплен. Следуя опыту китайских мастеров, мы использовали теплый раствор желатина, но по отечественной методике: 0,5\% теплый раствор желатина наносился флейцем с беличьим ворсом три раза с интервалом в сутки для полимеризации пленки [4, с. 35].

После закрепления красочного слоя стало возможным отделить «средники» от альбомных листов и удалить остатки старого клея. Для этой операции были использованы современные материалы, такие как холлитекс, мелинекс и тонкий шелк — газ. Эти материалы в значительной степени облегчили работу с увлажненной тонкой китайской бумагой (рис. 11).

Когда «средники» были отделены от альбомных листов, то стало видно, что живопись и каллиграфия выполнены на тончайшей китайской бумаге, которая в свою очередь была дублирована на такую же тонкую белую бумагу. Эта дублировка предохранила оригинальную основу под изображения от воздействия старого клея и микроорганизмов. После водной обработки в дистиллированной воде
10. Пример альбомного листа с поврежденными участками клея.

Лист № 27 в процессе реставрации. Государственный эрмитаж. Автор фотографии: Е.Г. Шишкова 
11. Процесс демонтажа «средников» со старого альбомного листа № 18.

Государственный Эрмитаж.

Автор фотографии: Е.Г. Шишкова

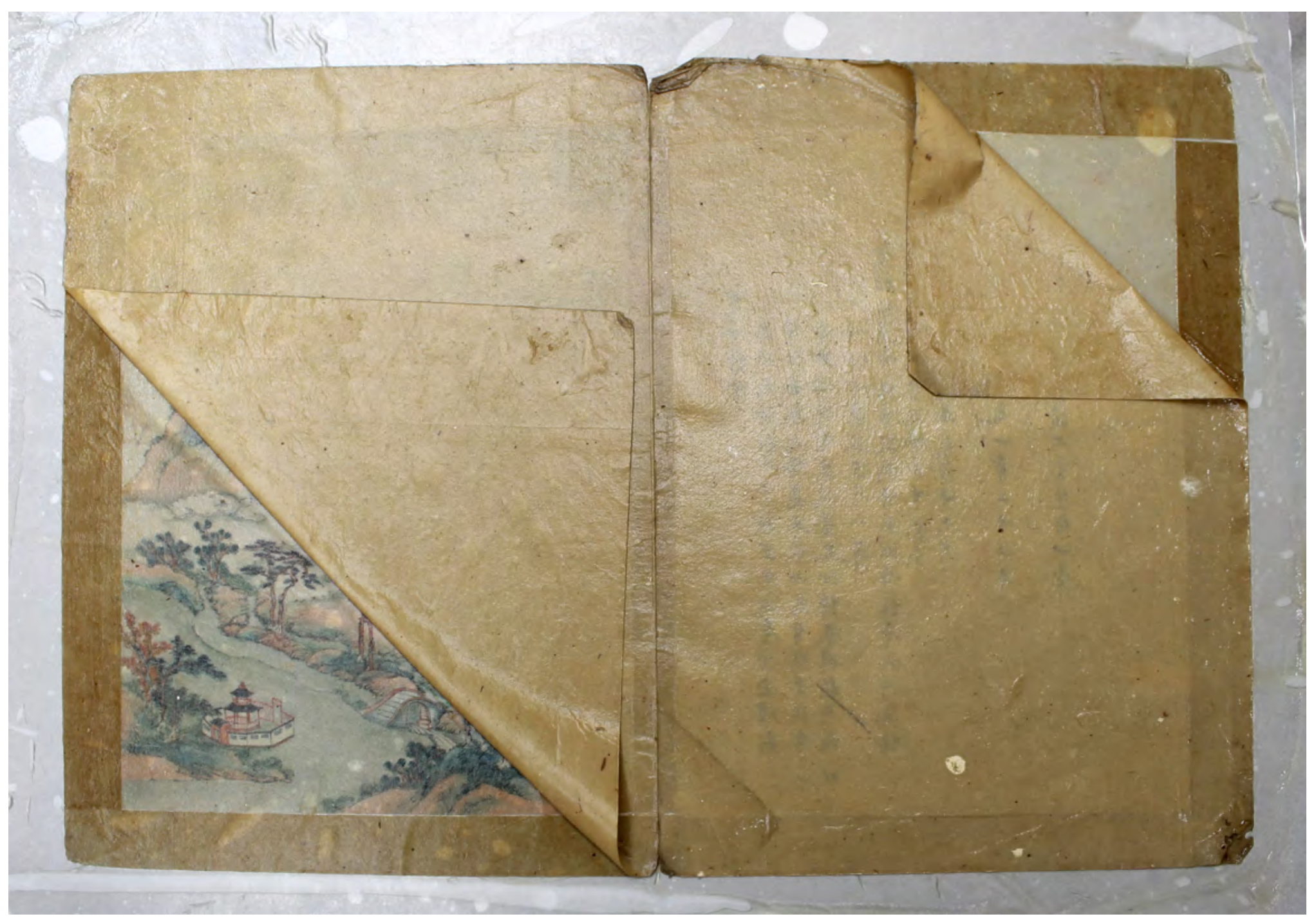

«средники» были перенесены с помощью листа холлитекса на фильтровальную бумагу для просушки.

Затем разрывы были подклеены тонкой японской бумаги Tengujo 5 г/м, а утраты основы и дублировочного листа восполнены анхойской бумагой.

Много времени потребовалось для изготовления шестислойной основы из анхойской китайской бумаги высокого качества для новых альбомных листов — «колодок» [3, с. 179]. На это ушло 42 листа китайской бумаги, которые сначала были дублированы парно, затем по три пары поэтапно. Из каждого шестислойного листа получилось два альбомных листа, а их должно было быть 14. Для дублирования использовался густой 5\% раствор клея из пшеничной муки, приготовленный по рецепту «Студии реставрации древней живописи и каллиграфии» Шанхайского музея. В процессе дублирования особое внимание уделялось влажности бумаги, так как переувлажнение листов могло вызвать их деформацию и образование затёков [1, с. 189]. Шелк однотонного бежевого цвета для обрамления картин был дублирован также на анхойскую бумагу.
Существует два типа монтирования «средника» в обрамление на «колодку» альбомного листа: пятичленное обрамление и прорезанное с фиксацией. Для монтирования эрмитажных «средников» в обрамление был выбран способ пятичленного обрамления, то есть обрамление живописного изображения пятью полосками цветного шелка по верхнему, нижнему, левому, правому краям и в центре по вертикали [1, с. 204, 245-247].

Подготовив все материалы для монтирования «средников» на новые «колодки» альбомных листов, специалисты провели расчеты материалов, рассчитали размеры обрамлений и выполнили нарезку их в заданный размер старого обрамления. Затем все элементы были одновременно соединены: «средники» дублированы на «колодки» новых альбомных листов, обрамлены полосками дублированного шелка и приклеены на «стену» для выравнивания методом растяжки (рис. 12). Обрамление из гладкого однотонного шелка придало картинам и текстам свежесть и нарядность [3, с. 180].

После выравнивания и высыхания монтированные «средники» были сняты со «стены», каждый лист был согнут посередине с предварительным 


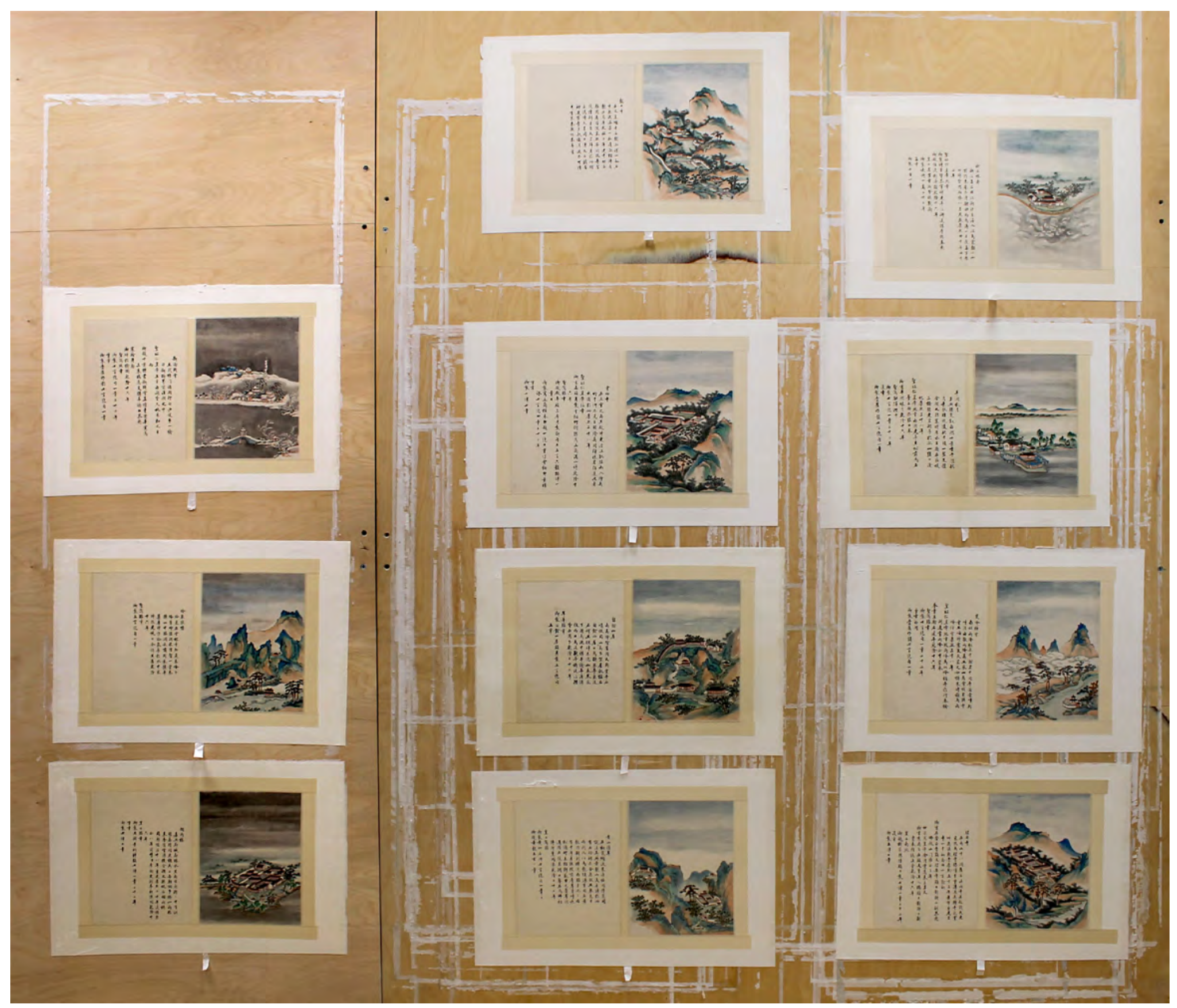

легким вертикальным надрезом на оборотной стороне. После сгиба листы были выровнены под прессом и затем обрезаны по трафарету в размер старого альбомного листа [1, с. 247; 13, с. 66].

Затем оборотная сторона каждого листа была обработана шлифовальным камнем с предварительным глянцеванием белым воском. Этот процесс называется «пемзованием», он обязателен для обработки как альбомных листов, так и оборотных сторон свитков. Таким образом, листы стали гладкими и пластичными [1, с. 233; 13, с. 63] (рис. 13).

Завершающим этапом работы с альбомом живописи было изготовление папки для хранения листов. Поскольку было решено не монтировать альбомные листы в форме «бабочки», а хранить их как отдельные парные листы, то форма хранения тоже изменилась: вместо крышек была изготовлена папка, обтянутая шелком-парчой с нефритовыми застежками. А старые альбомные листы были помещены в отдельной папке как оригинальная часть памятника XVIII века.

Такую форму хранения и экспонирования альбомных листов с живописными изображениями и каллиграфией можно наблюдать в различных музеях Китая, Кореи и Японии.

Папка была изготовлена из трех слоев бескислотного картона толщиной 1,2 мм, которые были дублированы между собой на 8\% клей из пшеничного крахмала и затем обтянуты шелком-парчой. В верхнюю и нижнюю крышки папки были вставлены петельки из шелковой тесьмы с вдетыми в них нефритовыми застежками для фиксации крышек между собой. На участках, где должны
12. Процесс выравнивания на «стене» дублированных «средников» с живописью и каллиграфией на новые альбомные листы - «колодки». Государственный Эрмитаж. Автор фотографии: Е.Г. Шишкова 


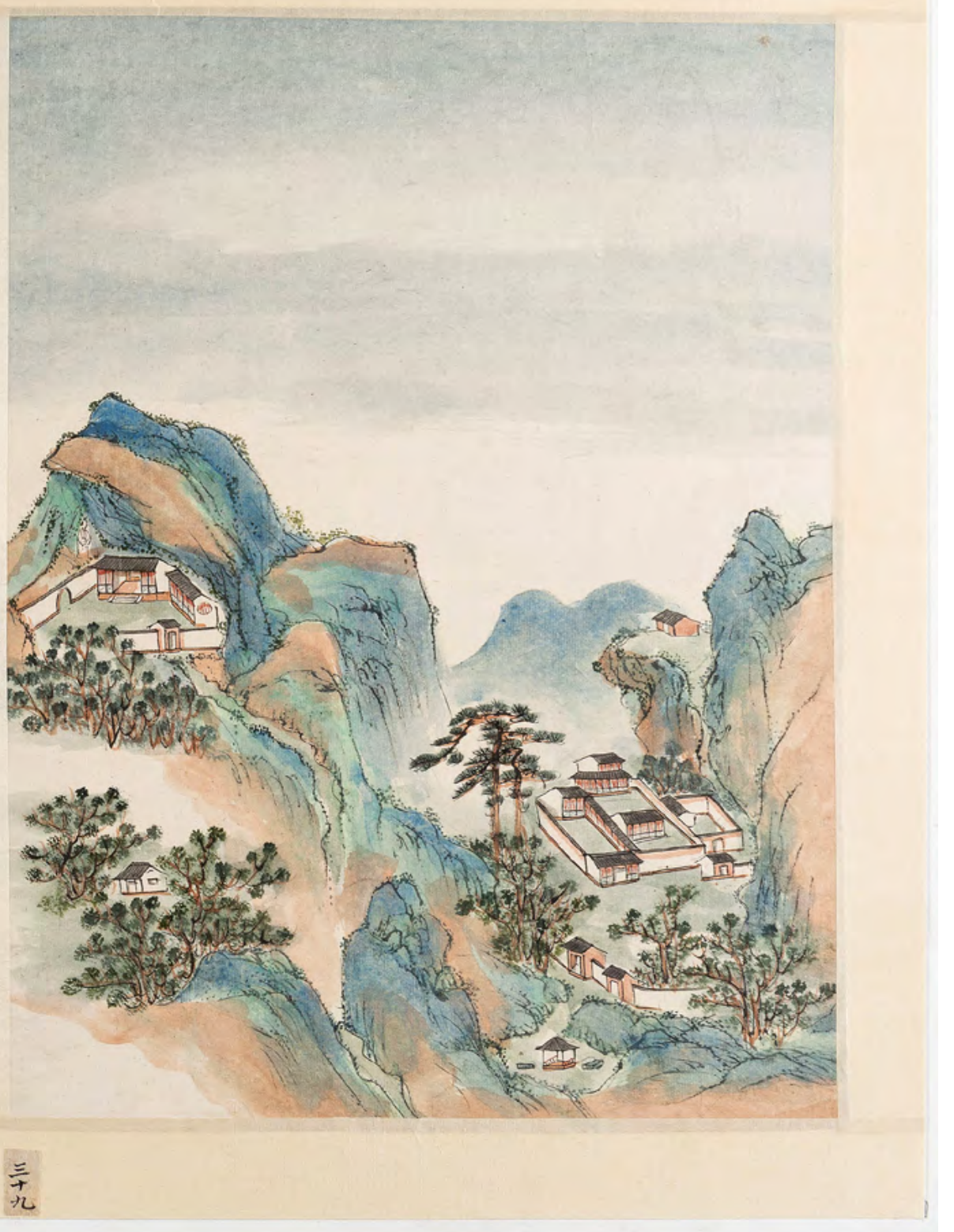

13. Лист № 18 после реставрации.

Государственный Эрмитаж.

Автор фотографии: К.В. Синявский были крепиться петельки, часть картона была выбрана, чтобы «утопить» края петель вровень с основным слоем картона. Внутренняя сторона крышек и корешка была проклеена двухслойной анхойской бумагой (рис. 14).

При изготовлении папки для хранения листов с живописными изображениями или текстами были тщательно измерены все элементы: крышки, корешки, места соединения крышек и корешка. Следует учитывать, что крышки должны быть в размер альбомных листов, а корешок должен «обнимать» стопку листов с запасом пространства в 2 мм. Крышки и корешок должны иметь «зазор» между собою по 2 мм с каждой стороны, и эти «зазоры» проклеиваются с внутренней стороны шелком вместо бумаги. Таким образом, устраняется чрезмерное давление на листы с изображениями, но вместе с тем исключается их выпадение из папки.

Такая форма хранения, с одной стороны, очень традиционна, а с другой стороны, она отвечает современным требованиям хранения и расширяет возможности дальнейшего экспонирования памятника (рис. 15). 


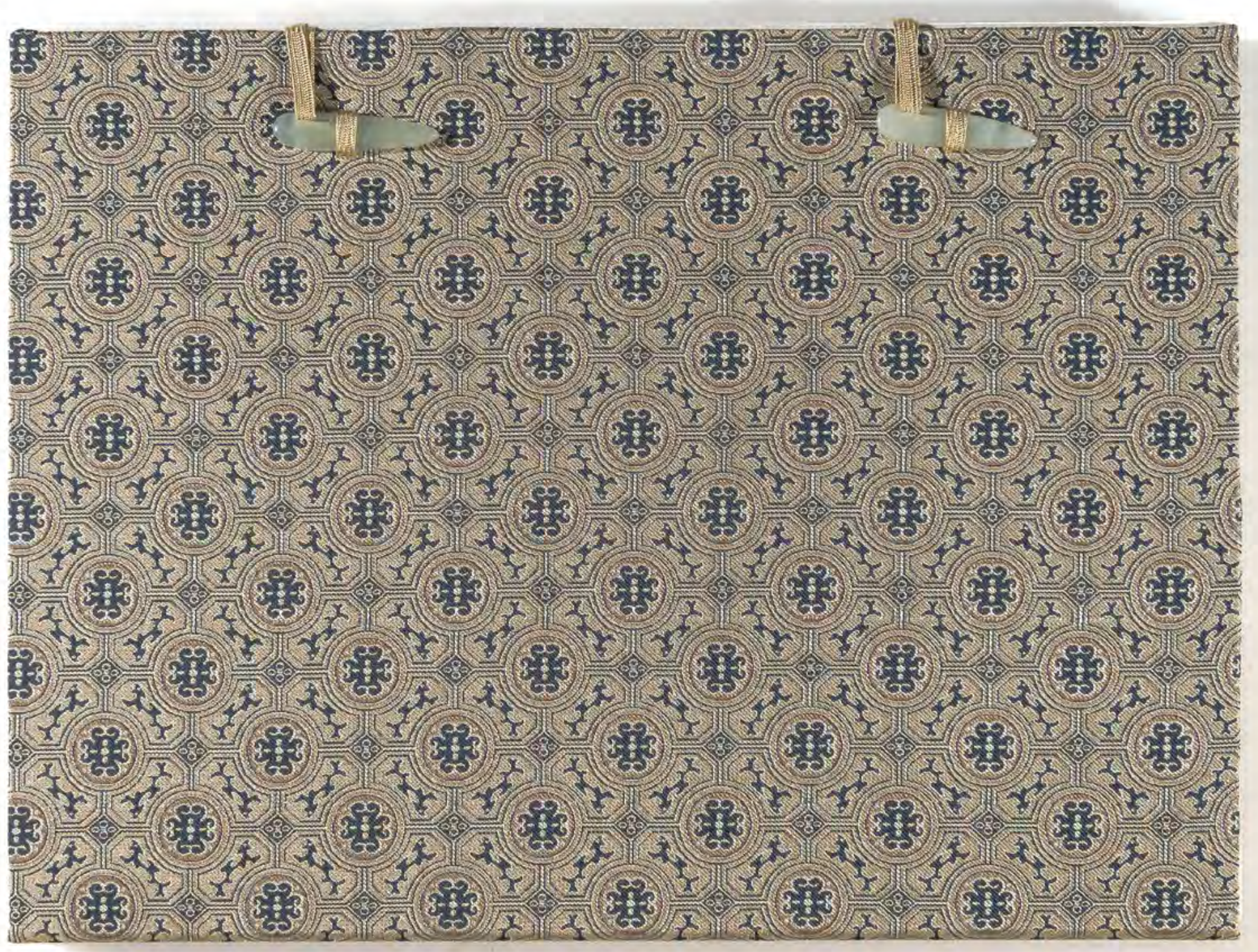

14. Папка

с альбомными листами после реставрации.

Государственный Эрмитаж.

Автор фотографии: К.В. Синявский

\section{Заключение}

Работа над альбомом длилась три года, она потребовала взвешенного решения по каждой последующей операции. Важную роль при выборе реставрационной методики сыграл опыт стажировок в «Студии научной реставрации живописи и каллиграфии» Шанхайского музея заведующей лабораторией научной реставрации восточной живописи Е.Г. Шишковой и художника-реставратора первой категории А.О. Дивлеткильдеевой в 2011, 2013 и 2019-х годах. Эти стажировки были возможны благодаря спонсорской поддержке фонда «The Coca-Cola Foundation» и Благотворительного фонда В. Потанина. Наблюдение за работой китайских реставраторов со старыми, поврежденными свитками и альбомами помогло в выборе программы реставрационных мероприятий по восстановлению эрмитажного альбома. Предварительное комплексное изучение и обследование памятника позволило выбрать необходимую методику реставрации. Изменение исторической формы хранения было вызвано сильным повреждением альбома и утратой оригинального переплета. Однако новая форма хранения расширила возможности изучения и экспонирования редкого образца китайской живописи. 
15. «Альбом рисунков.

Путешествие

императора

Цяньлуна на юг Китая».

Китай,

династия Цин,

1751, 1758 гг.

Государственный

Эрмитаж.

Альбом после

реставрации.

Автор фотографии:

А.О. Дивлеткильдеева

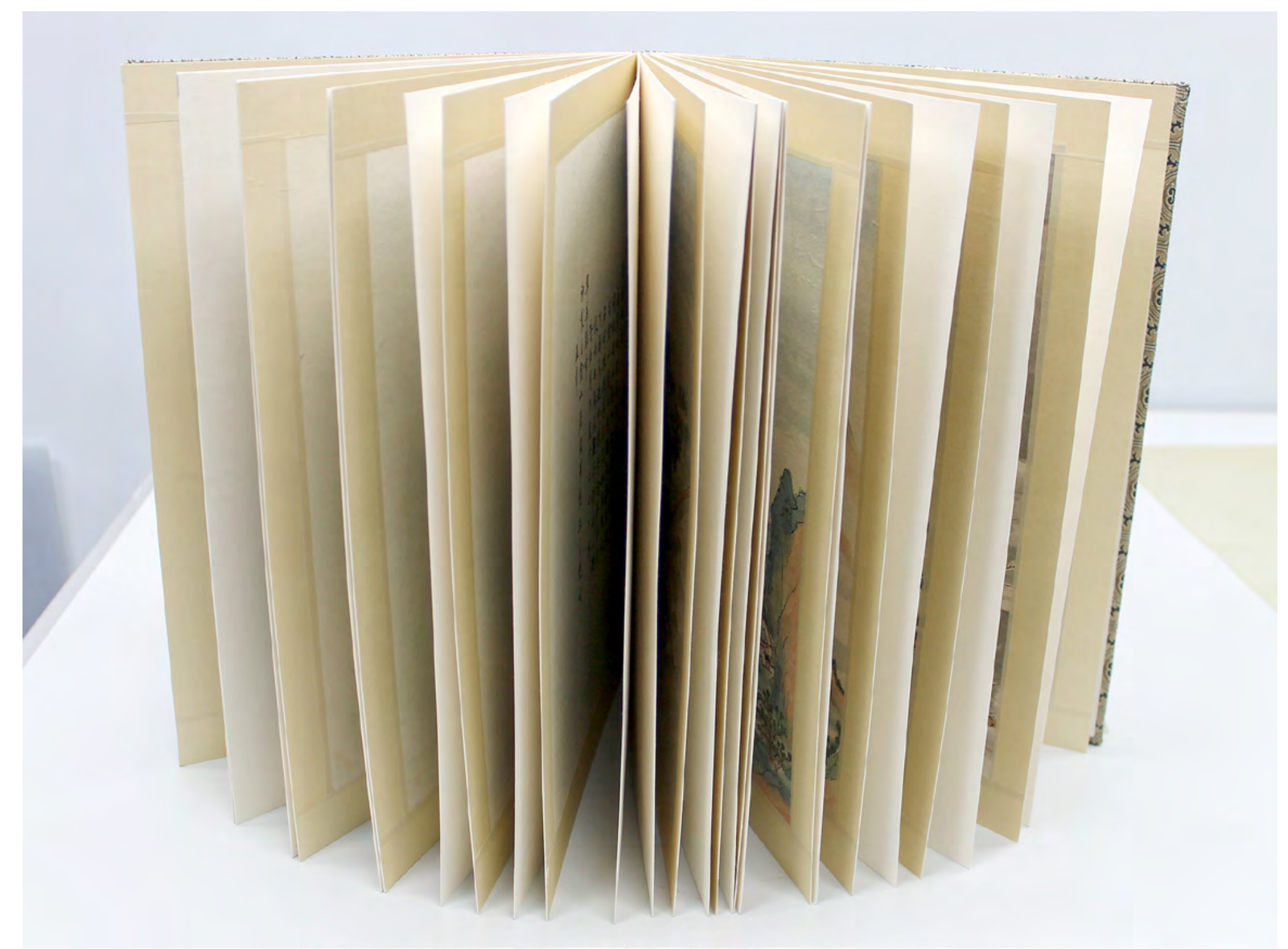

\section{Примечания}

1. Условия проведения рентгенофлуоресцентного анализа: $U=50$ kV, I=700 $\mu \mathrm{A}$, время накопления спектра 40 сек. Материал анода рентгеновской трубки - молибден.

2. Условия проведения инфракрасной Фурье-микроспектроскопии: МСТ детектор, область регистрации спектра 4000-400 см-1, разрешение $4 \mathrm{cм}^{-1}$, число сканов - 64.

3. Условия проведения рентгенофазового анализа: U=25 kV, I=5 mA, время экспозиции 10 мин. Материал анода рентгеновской трубки - хром. 


\section{Литература}

1. Белозерова В.Г. Китайский свиток. Москва: Государственный научно-исследовательский институт реставрации, 1995.272 с. URL: https://www.elibrary.ru/item.asp?id=36562218 (дата обращения: 20.09.2021).

2. Косолапов А.И. Естественнонаучные методы в экспертизе произведений искусства. Санкт-Петербург: Издательство Государственного Эрмитажа, 2010. 170 с.

3. Метлицкая Л.Л., Костикова Е.А. Реставрация произведений графики: Методические рекомендации. М.: ВХНРЦ им. И.Э. Грабаря, 1995. 183 с.

4. Одинокова П.С. Формат альбома в традиционном китайском искусстве // Декоративное искусство и предметнопространственная среда. Вестник МГХПА. 2017. № 4-1. С. 173-184.

URL: https://www.elibrary.ru/download/elibrary_32307855_55532510.pdf (дата обращения: 20.09.2021).

5. Смоляницкая О.Л. Микромицеты как потенциальные агенты биоповреждения культурных ценностей и стратегия защить от них в Государственном Эрмитаже. Дисс. канд. биол.наук. Санкт-Петербург: [Б. и.], 2007. 174 с.

6. Шишкова Е.Г. Об особенностях консервации произведений графики в альбомах // Альбом семьи Левашовых из собрания Государственного Эрмитажа: Реставрационный сборник З / отв. ред. В.Ю. Матвеев. СПб: АО Славия, 1999. 97 с.

7. Brown C. Great Qing. Painting in China, 1644-1911. Washington: University of Washington Press, 2014. 352 p.

8. De Campos Vidal B., Mello M.L.S. Collagen type I amide I band infrared spectroscopy // Micron. 2011. Vol. 42. P. $283-289$.

9. Kogou S., Lucian A., Bellesia S., Burgio L., Bailey K., Brooks C., Liang H. A holistic multimodal approach to the non-invasive analysis of watercolour paintings // Applied Physics A. 2015. Vol. 211. P. 999-1014. DOl: https://doi.org/10.1007/s00339-015-9425-4

10. Li T., Jinxin Ji J., Zhou1 Z., Shi J. A multi-analytical approach to investigate date-unknown paintings of Chinese Taoist priests // Archaeological and Anthropological Sciences. 2015. Vol. 9. P. 395-404

11. Liang H., Burgio L., Bailey K. et al. Culture and trade through the prism of technical art history: a study of Chinese export paintings // Studies and conservations. 2014. Vol. 59. P. 596-599. DOl: https://doi.org/10.1179/204705814X13975704318272

12. Roy A. (ed.). Artists' pigments: A handbook of their history and characteristics. Washington: National Gallery of Art, 1993.232 p.

13. 严桂荣。图说中国书画装裱 (第二版)。上海: 上海人民美术出版社, 2013. (Янь Гуйжун. Иллюстрированное руководство по монтированию китайской каллиграфии и живописи (2-е изд.). Шанхай: Шанхай жэньминь мэйшу чубаньшэ, 2013. 97 с.).

\section{ИНФОРМАЦИЯ ОБ АВТОРАХ:}

Шишкова Елена Григорьевна — кандидат искусствоведения, заведующая лабораторией научной реставрации восточной живописи, Государственный Эрмитаж, г. Санкт-Петербург, Российская Федерация, eshishkova@hermitage.ru

Самосюк Кира Федоровна - доктор искусствоведения, главный научный сотрудник отдела Востока, Государственный Эрмитаж, г. Санкт-Петербург, Российская Федерация, kira.samosyuk@yandex.ru

Дивлеткильдеева Анна Олеговна - художник-реставратор, лаборатория научной реставрации восточной живописи, Государственный Эрмитаж, г. Санкт-Петербург, Российская Федерация, anita_2683@mail.ru

Смоляницкая Ольга Львовна - кандидат биологических наук, заведующая лабораторией биологического контроля и защиты, Государственный Эрмитаж, г. Санкт-Петербург, Российская Федерация, smolyanitskaya@hermitage.ru

Хаврин Сергей Владимирович - заместитель заведующего, отдел научно- технологической экспертизы, Государственный Эрмитаж, Российская Федерация, sergekhavrin@yandex.ru

Чугунова Ксения Сергеевна - старший научный сотрудник отдела научно-технологической экспертизы, Государственный Эрмитаж, г. Санкт-Петербург, Российская Федерация, askachu@yandex.ru

Григорьева Ирина Андреевна - старший научный сотрудник отдела научно-технологической экспертизы, Государственный Эрмитаж, г. Санкт-Петербург, Российская Федерация, irinagrigorieva@mail.ru

Уразаева Яна Рустэмовна — кандидат химических наук, научный сотрудник, лаборатория научной реставрации драгоценных и археологических металлов, Государственный Эрмитаж, г. Санкт-Петербург, Российская Федерация, уana-hermitage@yandex.ru

\section{Для цитирования}

Шишкова Е.Г., Самосюк К.Ф., Дивлеткильдеева А.О., Смоляницкая О.Л., Хаврин С.В., Чугунова К.С., Григорьева И.А., Уразаева Я.Р. Реставрация китайского альбома XVIII века // Искусство Евразии [Электронный журнал]. 2021. № 4 (23). С. 254-269. DOI: https://doi.org/10.46748/ARTEURAS.2021.04.020. URL: https://eurasia-art.ru/index.php/art/article/view/799 


\section{References}

1. Belozerova V. G. Kitaiskii svitok [Chinese scroll]. Moscow, State Research Institute for Restoration Publ., 1995. 272 p. (In Russian). 2. Kosolapov A.I. Estestvennonauchnye metody v ehkspertize proizvedenii iskusstva [Natural science methods in the examination of works of art]. St. Petersburg, State Hermitage Museum, 2010. 170 p. (In Russian).

3. Metlitskaya L.L., Kostikova E.A. Restavratsiya proizvedenii grafiki: Metodicheskie rekomendatsii [Restoration of objects of graphic art: Methodological recommendations]. Moscow, The Grabar Art Conservation Center, 1995. 183 p. (In Russian).

4. Odinokova P. S. Format al'boma v traditsionnom kitaiskom iskusstve [Album Format in Traditional Chinese Art]. Dekorativnoe iskusstvo i predmetno-prostranstvennaya sreda. Vestnik MGKHPA — Bulletin of Moscow State Stroganov Academy of Design and Applied Arts, 2017, no. 4-1, pp. 173-184. (In Russian).

5. Smolyanitskaya O.L. Mikromitsety kak potentsial'nye agenty biopovrezhdeniya kul'turnykh tsennostei i strategiya zashchity ot nikh $\checkmark$ Gosudarstvennom Ehrmitazhe.[Micromycetes as Potential Agents of Biological Damage to Cultural Property and a Strategy for Protection from Them in the State Hermitage Museum. Diss. Cand. Biological Sciences.]. Saint-Petersburg, [S.n.], 2007. 174 p. (In Russian).

6. Shishkova E.G. Ob osobennostyakh konservatsii proizvedenii grafiki v al'bomakh [On the peculiarities of conservation of graphic works in albums]. Matveev V.Yu. (ed.). Al'bom sem'i Levashovykh iz sobraniya Gosudarstvennogo Ehrmitazha [Album of the Levashov family from the collection of the State Hermitage: Collection of restoration, No. 3]. St. Petersburg, Slaviya Publ., 1999. 97 p. (In Russian).

7. Brown C. Great Qing. Painting in China, 1644-1911. Washington, University of Washington Press, 2014. 352 p.

8. De Campos Vidal B., Mello M.L.S. Collagen type I amide I band infrared spectroscopy. Micron, 2011, vol. 42, pp. $283-289$.

9. Kogou S., Lucian A., Bellesia S., Burgio L., Bailey K., Brooks C., Liang H. A holistic multimodal approach to the non-invasive analysis of watercolour paintings. Applied Physics A, 2015, vol. 211, pp. 999-1014. DOl:1 https://doi.org/10.1007/s00339-015-9425-4

10. Li T., Jinxin Ji J., Zhou1 Z., Shi J. A multi-analytical approach to investigate date-unknown paintings of Chinese Taoist priests. Archaeological and Anthropological Sciences, 2015, vol. 9, pp. 395-404.

11. Liang H., Burgio L., Bailey K. et. all. Culture and trade through the prism of technical art history: a study of Chinese export paintings. Studies and conservations, 2014, vol. 59, pp. 596-599. DOl: https://doi.org/10.1179/204705814X13975704318272

12. Roy A. (ed.). Artists' pigments: A handbook of their history and characteristics. Washington, National Gallery of Art, 1993.232 p. 13. Yan Guirong. Illustrated Manual on Mounting of Chinese Calligraphy and Painting (second edition). Shanghai, Shanghai renmin meishu chubanshe, 2013. 97 p.

\section{ABOUT AUTHORS:}

Shishkova, Elena Grigorievna - Cand. Sc. (Art History), the Head of the Laboratory for the Scientific Restoration of Oriental Painting of the State Hermitage Museum, St. Petersburg, Russian Federation, eshishkova@hermitage.ru

Samosyuk, Kira Fedorovna - D. Sc. (Art History), the Chief Researcher of the Oriental Department, the State Hermitage Museum, St. Petersburg, Russian Federation, kira.samosyuk@yandex.ru

Divletkildeeva, Anna Olegovna - the Artist Restorer of the Laboratory for the Scientific Restoration of Oriental Painting, the State Hermitage Museum, St. Petersburg, Russian Federation, anita_2683@mail.ru

Smolyanitskaya, Olga Lvovna - Cand. Sc. (Biology), the Head of the Laboratory of Biological Control, the State Hermitage Museum, St. Petersburg, Russian Federation, smolyanitskaya@hermitage.ru

Khavrin, Sergey Vladimirovich - the Deputy Head of the Department of Scientific Examination of Works of Art, the State Hermitage Museum, St. Petersburg, Russian Federation, sergekhavrin@yandex.ru

Chugunova, Ksenia Sergeevna - the Senior Researcher of the Department of Scientific Examination of Works of Art, the State Hermitage Museum, St. Petersburg, Russian Federation, askachu@yandex.ru

Grigorieva, Irina Andreevna - the Senior Researcher of the Department of Scientific Examination of Works of Art, the State Hermitage Museum, St. Petersburg, Russian Federation, irinagrigorieva@mail.ru

Urazaeva, Yana Rustemovna - Cand. Sc. (Chemistry), the Researcher Assistant, the Laboratory for Scientific Restoration of Precious and Archaeological Metals, the State Hermitage Museum, St. Petersburg, Russian Federation, yana-hermitage@yandex.ru

\section{For citation:}

Shishkova E.G., Samosyuk K.F., Divletkildeeva A.O., Smolyanitskaya O.L., Khavrin S.V., Chugunova K.S., Grigorieva I.A., Urazaeva Ya.R. Restoration of 18th century Chinese album. Iskusstvo Evrazii - The Art of Eurasia, 2021, No. 4 (23), pp. 254-269. DOl: https://doi.org/10.46748/ARTEURAS.2021.04.020. Available at: https://eurasia-art.ru/index.php/art/article/view/799 (In Russian). 